\title{
Életem, munkásságom
}

\author{
BRÜCHER Ernö* \\ Debreceni Egyetem, Szervetlen és Analitikai Kémia Tanszék, Egyetem tér 1, 4032 Debrecen, Magyarország
}

\section{Bevezetés}

A hasonló kémiai tulajdonságú ritkaföldfém elemek (RFE) elválasztását az 1950-es években oldották meg és már a 90-es években a modern ipar, az információs és kommunikációs technológia számára stratégiai fontosságúak lettek. Érdekes, hogy jelentőségüket legkorábban Kínában ismerték fel és jelenleg a világtermelés mintegy 90\%-át Kína adja.

Én 1960-ban az ATOMKI-ban kezdtem az RFE radiokémiai elválasztásával foglalkozni, majd az 1970-es években már a debreceni Kossuth Lajos Tudományegyetemen dolgozva alakult ki körülöttem egy kis kutatócsoport, melynek eredményeit nemzetközi szinten is számontartották. Csoportunk tagjai közül többen egyetemi tanárok lettek itthon vagy külföldön (utóbbiak egyike az MTA külső tagja), két habilitált, volt PhD hallgatóm is hamarosan elkészíti MTA doktori értekezését. A Ritkaföldfém csoport (ahogy a tanszéken nevezték), jelenleg is él és eredményes, persze már régen nem az én vezetésemmel. Egy lényeges változás történt a csoport „életében”, mivel vezetőjét, Tircsó Gyula docenst a Fizikai Kémiai Tanszék vezetőjévé nevezték ki, így a csoport a Szervetlen és Analitikai Tanszékről is oda került.

Írásomban - némi bíztatásra - pályafutásom és kutatási témáink ki- és átalakulását, eredményeinket, fontosabb közleményeinket és ebben a magam és kollégáim, (volt tanítványaim) szerepét mutatom be.

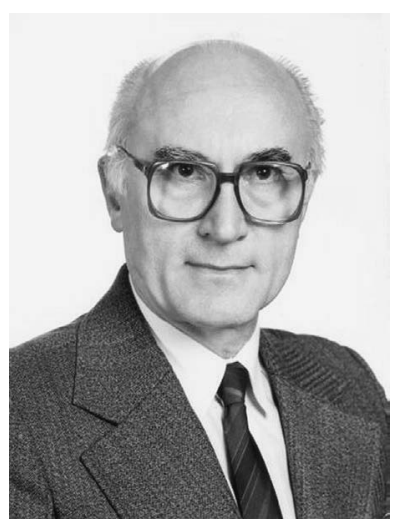

1935-ben Balmazújvároson születtem késői, ötödik gyerekként. Apám egy kihalóban lévő mesterséget folytatott, családi hagyományként takács kisiparos volt. Kémiával már kisgyerekként találkoztam (bár ezt akkor nem tudtam), mivel apám időnként klórmésszel fehérített. Az elemi iskola első 4 osztályát 1941-45 között végeztem és 1945 őszén kortársaimmal mi kezdtük el az akkor bevezetett nyolcosztályos általános iskola felső tagozatát, amit 1949-ben fejeztem be. Ezután felvettek a debreceni Fazekas Mihály
Gimnáziumba, ahol rám legnagyobb hatással kémiatanárunk, Kulcsár László volt, aki a hadifogságból hazatérve megkezdte az iskola kémiaszertárának rendbetételét és ehhez néhányunkat segíteni invitált. Ekkor láttam (és mosogattam) először laboratóriumi eszközöket és néztem kémiai kísérleteket, amiket Tanár úr gondolom, érdeklődésünk felkeltésére bemutatott. Esetemben ez sikerült is, amit később egy barátom tovább erősített, aki aztán két évvel előttem végzett az egyetemen vegyész szakon.

Sajnos, apám 1946-ban beteg lett, nem tudott dolgozni. A gondok csökkentésére a nyári szünetekben mindig dolgoztam. A gimnázium III. osztálya befejezése után az iskola igazgatója javasolta, hogy jelentkezzek a Szovjetunióba egyetemi tanulmányokra és az azt előkészítő iskolába. Így 1952 szeptemberétől Budapesten tanultam a Szovjet Ösztöndíjas Előkészítő Intézetben. Ott a mindennapi orosz nyelvórák mellett matematika és fizika óráink is naponta voltak, ami jó előkészületnek bizonyult az egyetemi tanulmányokra. 1953 nyarán kitünő eredménnyel érettségiztem, de nem vittek ki a Szovjetunióba, viszont felvettek a KLTE vegyész szakára. Az egyetemen jól tanultam és a II. éves vizsgák, gyakorlatok után dolgozni hívtak a Kísérleti Fizikai Intézetbe. 1958 márciusában kitüntetéses vegyész oklevelet kaptam és kineveztek tudományos gyakornoknak az MTA Atommagkutató intézetébe (ATOMKI).

\section{Munkám az ATOMKI-ban}

Az ATOMKI-ban első munkám a szenek (és hamu) urán tartalmának és az urán(IV) humuszanyagokon történő adszorpciójának a vizsgálata volt. 1960-ban feladatom lett a radioaktív ritkaföldfém izotópok ioncserélő kromatográfiás elválasztása és tisztítása magspektroszkópiai célokra, majd Ra-228 és Ac-228 izotóp-készítményeket állítottam elö $[1,2]$. Szerencsémre nem kaptam túl sok feladatot, így lehetőségem volt önálló kutatásra is. Tanulmányoztam a ritkaföldfém(III) ionok $\mathrm{Ln}$ (III) $\mathrm{NH}_{4}$-laktáttal történő ioncserés elválasztása közben végbemenő reakciókat, az oldat- és gyantafázisban képződő Ln(III)-laktát komplexek összetételét. A kapott eredményeket [3] az egyetemi doktori értekezésemben foglaltam össze. Közben munkahelyet változtattam és 1963. október 15-től a KLTE Szervetlen és Analitikai Kémiai Tanszék izotóplaboratóriumában dolgoztam tudományos munkatársként.

* Tel.: +36 52512 900; ebrucher@science.unideb.hu

126. évfolyam, 3. szám, 2020. 


\section{Munkám a Tanszéken}

A Tanszéken Szarvas Pál tanszékvezető hozzájárulásával folytattam az RFE elválasztásával kapcsolatos munkát. A makromennyiségü RFE elválasztását 1952-55 körül oldották meg $\mathrm{Cu}^{2+}$ visszatartó-ion formában lévő kationcserélő oszlopon EDTA-val végzett elúcióval [4.]. Gondot okozott a nagyobb rendszámú elemek elválasztása, melyek gyakran megkötődés nélkül ,átfolytak” az oszlopon. Ezt a problémát feltehetően az LnEDTA komplexek lassú disszociációja okozta és ennek vizsgálatára tanulmányoztam az LnEDTA komplexek központi ionja kicserélődési reakcióinak kinetikáját és két-két $\mathrm{Ln}^{3+}$-ion ioncserés elválasztásakor nyert u.n. áttörési görbéket. Ez utóbbiak alapján számolhatók az oszlop hatékonyságát jellemző paraméterek, melyek a pH növelésével egyre jobban megközelítették a komplexek által disszociáció nélkül az oszlopban megtett utat, amit a kinetikai adatokból számoltam és ami jelezte az oldat-kinetikai tényezők szerepét az ioncserés elválasztásban [5]. Megállapítottam, hogy a Ln(EDTA)-komplexek izotóp-kicserélődési reakciói a komplexek protonkatalizált diszszociációjával, vagy a kicserélő ionok direkt támadásával mennek végbe. A merevebb Ln(DCTA)-komplexek cserereakciói csak protonkatalizált disszociációval folynak le. A sebességi állandók a ritkaföldfémek rendszámával úgy változnak, mint a komplexek stabilitási állandóinak reciprokai [6]. A tapasztalatok alapján egy új eljárást dolgoztam ki a ritkaföldfém hasadási termékek elválasztására EDTA- $\mathrm{NH}_{4}$ laktátos elúcióval, amikor az EDTA-val elérhető nagyobb elválasztási tényezők érvényesülnek, de a gyantafázisban a gyorsabban diffundáló $\mathrm{Ln}^{3+}$-laktát komplexek képződnek [7]. A fenti eredmények alapján készítettem el kandidátusi értekezésem, amit 1969-ben védtem meg.

1968-ban öthónapos tanulmányúton voltam Kijevben az Ukrán Akadémia Szervetlen Kémiai Intézetében K. B. Jacimirszkij professzor osztályán. Ebben az időben kaptak egy $60 \mathrm{MHz}$-es NMR készüléket, így a ritkaföldfémek spektroszkópiája mellett a ${ }^{1} \mathrm{H}-\mathrm{NMR}$ komplexkémiai alkalmazásával is ismerkedtem [8].

1970-ben docensi kinevezést kaptam és megbíztak a IV. éves vegyészek „Modern szervetlen kémia” című előadásai tartásával.

\section{Kutatócsoportunk kialakulása}

Az egyetem új kémiai épületét 1969-ben adták át, amikor bővültek a laboratóriumi munkahelyi lehetőségek és 1971ben egy fiatal, de az egyensúlyi kémiában már jártas kolléga, Király Róbert csatlakozott hozzám. Nemsokára két tehetséges II. éves hallgató, Tóth Imre és Zékány László jelentkezett munkára, akik pár év múlva a szintén szorgalmasan dolgozó Laurenczy Gábor és Bányai István hallgatókat hozták a laborba, és rendszeresen 1-2 diplomamunkás hallgatóval is bővült a csoport. Részletesen tanulmányoztuk több, $\mathrm{Ln}^{3+}$-aminopolikarboxilát rendszer egyensúlyát

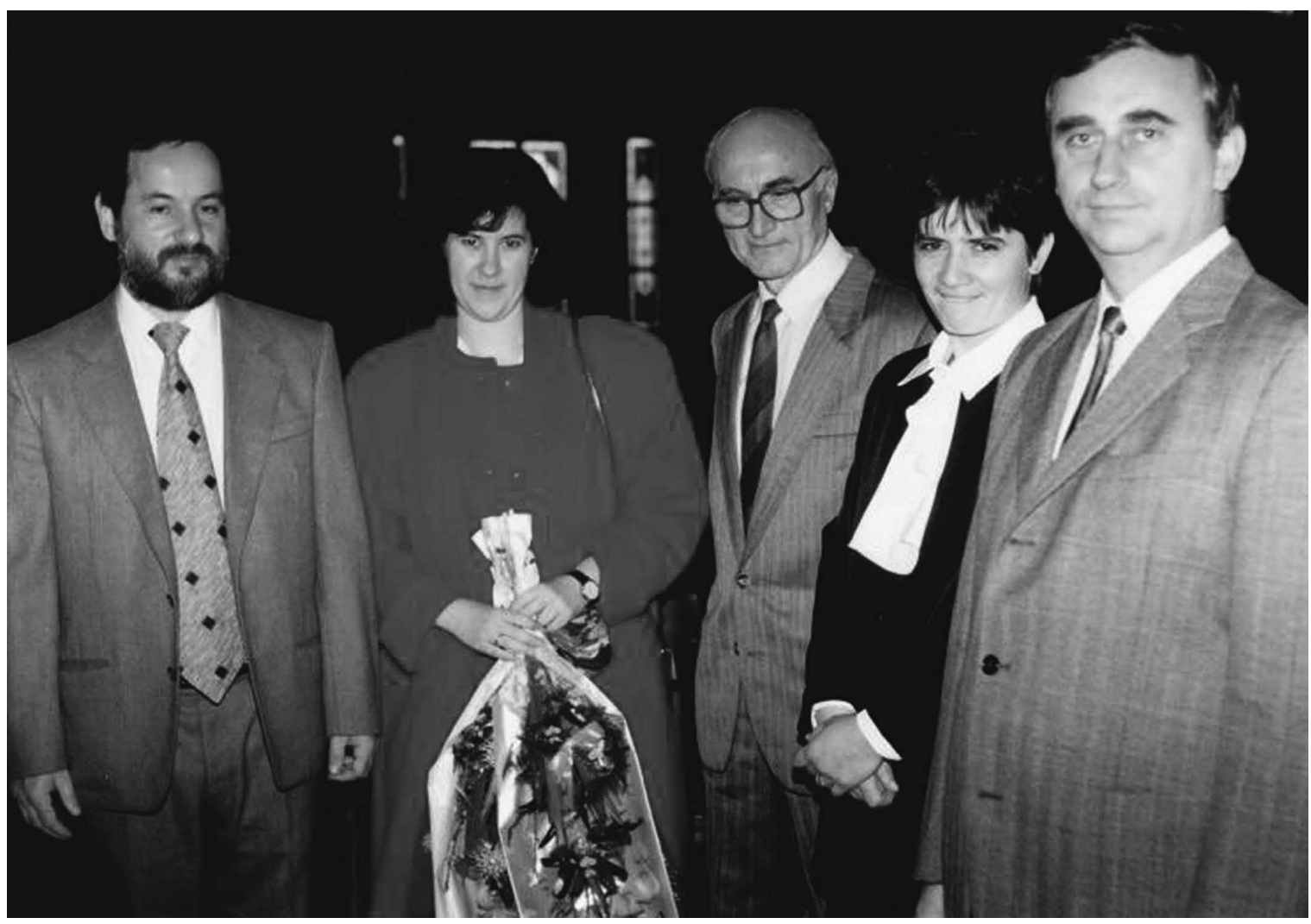

Dr. Tóth Imre (DE, TTK, Fiz. Kém. Tanszék, emeritusz professzor), Dr. Jakab-Tóth Éva (CNRS, CBM, Orleáns, Franciaország), Brücher Ernő majd Dr. Solymosi Piroska, és Dr. Király Róbert, nyugalmazott egyetemi docens (DE, TTK, Szervetlen és Analitikai Kémiai Tanszék) Debrecenben 1994-ben Tóth Éva doktoravatási ünnepsége után 
$\mathrm{Ln}^{3+}$-ion és ligandum felesleg jelenlétében. Az Ln(EDTA)komplexek protonálódási állandói a stabilitási állandók növekedésével csökkennek, míg az Ln(DTPA) ${ }^{2-}$-komplexek esetén nem változnak [9]. A Ln(EDTA) $)_{2}$-és a Ln(HEDTA) $)_{2}^{-}$ komplexek $\log K$ értékei maximum görbe szerint változnak a rendszámmal, a maximum a sorozat közepén van (a második ligandum csak egy iminodiacetát (IMDA) csoportjával koordinálódik). Az $\operatorname{Ln}_{2}(\mathrm{EDTA})_{3}$ kétmagvú komplexekben egy EDTA ${ }^{4-}$ ligandum hidat képez két Ln(EDTA)--komplex között. [10]. Ez a középső, összekötő ligandum lehet HDTA $^{4-}$ is, amikor stabilabb a kétmagvú komplex [11]. Bizonyítottuk a Ln(EDTA) $)_{2}$-komplexek képződését a ritkaföldfémek EDTA-val végzett anioncserés elválasztásakor, amikor a megoszlási hányadosok is maximum görbe szerint változnak a rendszámmal [12]. A hatfunkciós EDTA- és HEDTA-komplexekben 2-3 koordinációs helyre kötődhet a második ligandum, míg a $\operatorname{Ln}(\mathrm{DTPA})^{2-}$-komplexekben csak egy szabad koordinációs hely van, ezért pl. nagyon kis stabilitású Ln(DTPA)X vegyeskomplexek képződnek [13]. Ebben a munkában részt vett V. Hietapelto, aki 3 hónapos tanulmányúton volt nálunk az Oulu-i (Finnország) Egyetemröl. A Ln(EDTA)X vegyeskomplexek képződése a donoratomok kötéstávolságának növekedésével jár, ami pl. a $\mathrm{Ce}^{3+}$ vagy $\mathrm{Tb}^{3+} 4 \mathrm{f}-5 \mathrm{~d}$ sávjai kék irányú eltolódását és az Y(EDTA)- és La(EDTA)- ${ }^{-1}$ H-NMR spektrumában az AB multiplett jelek „összeolvadását” eredményezi [14].

A Ln(EDTA)--komplexek Ni(II), Co(II), Cu(II) és Pb(II) ionokkal lefolyó fémioncsere reakciói a protonált Ln(EDTA)disszociációjával és a kicserélő fémion komplexen történő direkt támadásával folynak le. A direkt reakciók sebessége a támadó fémionok vízcsere sebességével arányos, amit egy Ln(EDTA)M szimmetrikus köztitermék képződésével értelmeztünk [15].

A fémioncsere reakciók kinetikájának leírására egy általános sebességi egyenletet vezettünk be. Ez tartalmazza valamennyi lehetséges reakcióutat, az ezeket jellemző sebességi állandók a kísérleti pszeudo-elsőrendű sebességi állandókból számolhatók [16]. A legáltalánosabban előforduló reakcióút a komplexek protonkatalizált diszszociációja, melynek sebessége a különböző komplexekre a $\operatorname{Ln}($ HEDTA $)>\operatorname{Ln}($ EGTA $) \sim \operatorname{Ln}($ EDTA $)>\operatorname{Ln}($ DCTA $)>$ Ln(DTPA) sorrendben csökken $[15,16]$. Protonálódás hatására a $\mathrm{Ce}(\mathrm{EDTA})^{-}$metilén protonjai $\mathrm{AX}$ multiplett jele kiszélesedik, ami egy protonált IMDA csoport „,kifordulásával" kapcsolatos és ennek a folyamatnak a sebességi állandója aránylag jól egyezik a Ce(EDTA) protonkatalizált disszociációsebességi állandójával, jelezve, hogy a disszociáció sebességmeghatározó lépése az egy IMDA csoporttal koordinálódó köztitermék képződése [17].

Az Ln(EDTA) 'és Ln(EGTA)- -komplexek és a DTPA közötti ligandumcsere reakciók sebessége a pH függvényében minimum görbék szerint változik. Kisebb pH értékeknél a komplexek protonkatalizált disszociációjával, a $\mathrm{pH}$ növelésével a DTPA közvetlen támadásával, vegyes ligandumú köztitermék képződésével megy a reakció $[18,19]$.
Azt a feltevést, hogy a $\mathrm{Ln}^{3+}$ sorozat elején $\mathrm{Ln}(\mathrm{EDTA})\left(\mathrm{OH}_{2}\right)_{3}$, közepétől $\operatorname{Ln}(\mathrm{EDTA})\left(\mathrm{OH}_{2}\right)_{2}$ komplexek vannak jelen, a $\mathrm{K}[\mathrm{Ln}(\mathrm{EDTA})]$ komplexek látszólagos moláris térfogat értékei meghatározásával alátámasztottuk [20].

Az 1970-81 közötti eredményeink alapján nyújtottam be a Kémiai Tudomány Doktora értekezésemet, amit 1982-ben megvédtem és 1983-ban egyetemi tanárnak neveztek ki.

\section{Tanszékvezetői kinevezésem}

1975-ben Tanszékünk vezetője, Szarvas Pál nyugdíjba ment. Utódja Gergely Arthur docens lett, aki a Szarvas prof. által tartott előadásokat nem vette át, hanem engem bízott meg az „Általános kémia” és a „Szervetlen kémia” előadások egy részének megtartásával. Az első néhány év elég nehéz volt, mivel az előadott anyag módosítását, modernebb, anyagszerkezeti alapokon történő tárgyalását nagy várakozás előzte meg. A hallgatók felkészülésének segítésére „Általános kémia (Anyagszerkezet)” és „Szervetlen kémia (Fémek)" címmel előadás jegyzeteket írtam.

1978-ban Gergely Arthur tanszékvezetőt tudományos rektorhelyettesnek nevezték ki, így kevés ideje maradt a Tanszék ügyeire és engem javasolt tanszékvezetőnek. A megbízást 1980 nyarán kaptam meg. A Tanszék helyzete ekkor elég vegyes képet mutatott, de a jövőt illetően, több fiatal oktató felvételével sokat javult. A laboratóriumi gyakorlatok anyagának átalakítása, javítása már korábban megkezdődött és néhány kolléga sok időt, energiát fordított erre. A tudományos munka több kisebb csoportban folyt, aminek első eredményei már mutatkoztak.

$\mathrm{Az}$ egyetemi és tudományos közéleti munkába az 1960-as évek végétől vontak be. Több évig voltam a Magyar Kémikusok Egyesülete megyei titkára. 1969-75 között az oktatás koordinálására létrehozott „Kémiai Tanszékcsoport" titkára, majd 1975-78 között annak vezetője voltam. 1979-ben az Egyetemi Tanács tagjává választottak. 1984-86 között a Kémiai Intézet igazgató helyettese, a következő 2 évben pedig vezetője voltam.

Az 1970-73-as években az MTA Kromatográfiás Munkabizottság, 1973-tól az MTA Koordinációs Kémiai Munkabizottság tagja voltam. 1976-83 között a Tudományos Minősítő Bizottság Szervetlen Kémiai Szakbizottsága tagjaként tevékenykedtem. 1980-ban jelöltek az MTA FizikaiKémiai és Szervetlen Kémiai Bizottsága tagjai sorába. Számos kandidátusi és tudományok doktora védésen müködtem közre bizottsági tagként vagy bírálóként.

\section{Nemzetközi kapcsolatok}

A ritkaföldfémek koordinációs kémiájával 1985 előtt elég kevesen foglalkoztunk, de a közlemények alapján tudtunk egymásról. 1971-ben a brit-magyar kulturális csere keretében Peter Glentworth, a Leeds-i Egyetem docense látogatott meg. A koordinációs kémia legfontosabb konferenciája az

126. évfolyam, 3. szám, 2020. 
ICCC, amelyen először 1973-ban, Moszkvában vettem részt. Itt sokat beszélgettem G. Geier (Zürichi Egyetem) és A. E. Merbach (Lausanne-i Egyetem) kollégákkal. A következő évben meghívtak Svájcba, ahol a Lausanne-i, Fribourg-i és Zürich-i Egyetemeken beszéltem a vegyes komplexek képződésével kapcsolatos munkánkról. Merbach professzor meghívásai 2-3 évenként folytatódtak és 1985-ben 1 évre fogadta fiatal munkatársamat, Laurenczy Gábort, akit aztán ott is tartottak és aki ez évben a Kémiai Intézet professzoraként ment nyugdíjba.

1975-ben az NDK-ban szervezett „Komplexek az Analitikában" c. konferenciára, 1979-ben a Moszkvai Összövetségi Ioncserés Konferenciára hívtak meg előadóként. 1980-ban Smolenice-ben a 8. Koordinációs Kémiai Konferencián tartottam plenáris előadást. 1984-ben V. Veksin az Izsevszki Állami Udmurt Egyetemről érkezett hozzánk öthónapos tanulmányútra.

Sajnos fiatalabb koromban nem sikerült hosszabb tanulmányútra eljutnom (volt ugyan egy meghívásom az USA-ba D. W. Margerumhoz 1967-ben, de nem engedtek ki), ezért amikor Ingmar Grenthe professzor, a stockholmi Királyi Müszaki Egyetemre hívott, elfogadtam a meghívást és 10 hónapot az egyetem Szervetlen Kémiai Intézetében dolgoztam az $\mathrm{Ln}^{3+}$-ionok hidratációjának és az uranil-karbonato komplex ligandumcsere reakciói kinetikájának NMR-es vizsgálatán [21, 22]. Hazajövetelem után Tóth Imre kollégámat fogadták, aki aztán összesen 5 évet töltött Stockholmban. 1983-ban a velencei I. f-elem Konferencián megismerkedtem J. F. Desreux liege-i kollégával, aki 2 év múlva a zürich-i II. f-elem Konferencián örömmel újságolta, hogy kutatási témánk „divatba jött”, mivel a $\mathrm{Gd}^{3+}$-aminopolikarboxilát komplexek a mágneses rezonanciás képalkotás (MRI) alkalmazása során kontrasztanyagként használhatók. A Gd-alapú kontrasztanyagok két alap liganduma a nyíltláncú DTPA és a makrociklusos DOTA. Mivel az Ln(EDTA) és Ln(DTPA) komplexekröl több cikket is közöltünk [15-19], 1986-ban meghívtak a kanadai Hamiltonban rendezett 17. Ritkaföldfém Kutatási Konferencia Koordinációs Kémiai Szekciójába plenáris előadónak. Költségeim fedezésére elöadói körutat szerveztek hat amerikai egyetemre. Ekkor találkoztam a Birmingham-i (Alabama) Egyetemen a Budapeströl kivándorolt G. Elgavish, majd Dallasban A. D. Sherry professzorokkal. Utóbbival ismereteink, érdeklődésünk jól kiegészítették egymást, ezért meghívott 1 évre dolgozni. Az engedélyek beszerzése után 1988. június 15-től a Dallasi Texas Egyetemen kezdtem el a munkát. Augusztusban feleségem és kisebbik lányom is követtek. (Idősebb lányom ekkor már fogorvosként dolgozott.) Mivel a munka jól ment, jöttek az eredmények, az 1 évböl 2 év amerikai tartózkodás lett. 1989 nyarán Lázár István kollégám követett Dallasba és Ö is 2 évet töltött ott. 1992-ben Kovács Zoltán utazott az USA-ba, aki azóta is ott dolgozik. Néhány évvel később Tircsó Gyula töltött közel 4 évet Dallasban. Öt sikerült visszahívni. Közben Kálmán Ferenc $\mathrm{PhD}$ hallgatóm is dolgozott ott fél évet. Az ismétlődő meghívások a debreceniek eredményes munkáját jelzik. A Dallas-Debrecen 1988 óta tartó együttműködés alatt 45 kö-

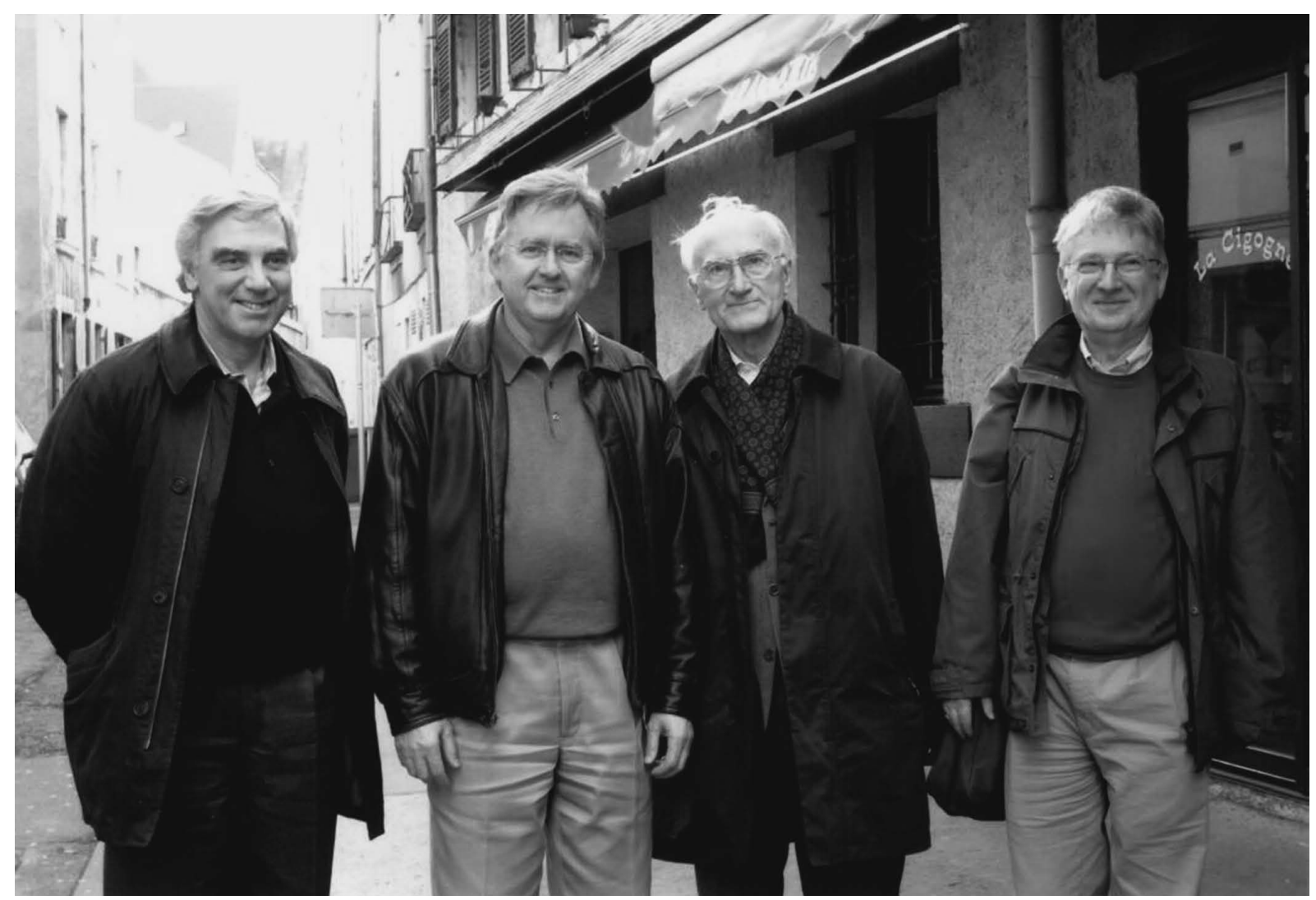

Carlos Geraldes (Coimbra), A. Dean Sherry (Dallas) és Joop Peters (Delft) profeszorokkal a Heidelbergi COST konferencián 
zös közlemény ill. szabadalom született, ezért nem meglepő, hogy A. Dean Sherry professzor a Debreceni Egyetem díszdoktora lett 2019-ben. A debreceni post doc-ok fogadása, a szakmai együttműködés és számos közös közlemény alapján, kezdeményezésünkre korábban már A. E. Merbach és S. Aime (Torino) professzorok is az egyetem díszdoktorai lettek.

\section{MRI kontrasztanyagok}

A jelenleg használt legfontosabb kontrasztanyag a Gd(DOTA) (Dotarem), és más Ln(DOTA)-komplexek képződése egy protonált köztiterméken keresztül lassan történik. Disszociációja proton katalizált úton megy végbe, ami fiziológiás $\mathrm{pH}$ esetén rendkívül lassú. A képződés és disszociáció mechanizmusára tett javaslatunkat a szakma elfogadta [23, 24]. Előzetes eredményeinket a III. f-elemek Konferencián, 1987-ben Lisszabonban mutattam be, ahol a Koordinációs Kémiai Szekció program koordinátora voltam.

Dallasi munkám során az ott előállított számos triaza-triacetát, tetraaza-tetraacetát, tetra-foszfonát és tetra-foszfinát $\mathrm{Gd}^{3+}$ - és néhány endogén fémionnal képezett komplexe stabilitási állandóját, a $\mathrm{Gd}^{3+}$-komplexek relaxivitását és kinetikai stabilitását állapítottam meg [25-31].

Dallasból 1990 júliusában tértem haza, amikor már a Tanszéken várt egy post doc a Kairói Egyetemről, aki 1 évig maradt nálunk. A Kassai Müszaki Egyetemről érkezett Jakab Sándor és az akkor végzett Tóth Éva és Solymosi Piroska is megkezdte doktori munkáját. Ennek során elöállítottuk a makrociklusos 18 -ane- $\mathrm{N}_{2} \mathrm{O}_{4}$-bis(malonát) ligandumot, ami két nagyságrenddel stabilisabb komplexet képez $\mathrm{Sr}^{2+}$-mal, mint $\mathrm{Ca}^{2+}$-mal [32]. Az új ligandum az Országos Sugárbiológiai Intézetben végzett állatkísérletek szerint alkalmas a Sr-izotóp élő szervezetből történő eltávolítására.

A klinikai MRI vizsgálatokban használt Gd(III)komplexekben a ligandum 8 donoratomja mellett egy vízmolekula is koordinálódik a $\mathrm{Gd}^{3+}$-ionhoz. A $\mathrm{Gd}^{3+}$ komplexek relaxációs hatása a vízmolekula cseresebességétől is függhet. A vízcserét nagyon gyorsnak és aszszociatív úton lefolyónak gondolták. Én valószínübbnek tartottam a lassabb, disszociatív vízcserét. A vízcsere sebesség ${ }^{17} \mathrm{O}-\mathrm{NMR}$ spektroszkópiásan mérhető, de a 90-es évek elején erre Debrecenben még nem volt lehetőség. Sikerült a probléma iránt Merbach prof. érdeklődését felkelteni és Micskei kollégám 1992-ben elvégezte a méréseket Lausanne-ban. Megállapítottuk, hogy a $\operatorname{Gd}(\mathrm{DTPA})\left(\mathrm{H}_{2} \mathrm{O}\right)$ és $\mathrm{Gd}(\mathrm{DOTA})\left(\mathrm{H}_{2} \mathrm{O}\right)$ esetében a vízcsere sebessége több, mint két nagyságrenddel kisebb, mint a $\mathrm{Gd}^{3+}$ aq ion esetében, így befolyásolja a komplex relaxációs hatását [33, 34]. Ezután több $\mathrm{PhD}$ hallgatóm dolgozott 1-2 évet Lausanne-ban közös témán. Tóth Évát 11 év lausanne-i munka után hívták az orleans-i CNRS intézetbe dolgozni, amelynek később igazgatója is lett.
Az 1990-es években az EU tudományos programja keretében Merbach professzorral megszerveztük az európai ritkaföldfém komplexekkel foglalkozók összefogását a COST programok támogatásával. Ezekben kezdetben 10 kutatócsoport vett részt és az évenkénti konferenciáink (a II. Budapesten került megrendezésre) nagyon sikeresek voltak. Egy francia orvoscsoporthoz kapcsolódva résztvettünk az EU F6-os kutatási programjában is.

Közben a Schering A. G. gyógyszergyárral kötött kutatási szerződés keretében nagyszámú nyíltláncú és makrociklusos ligandum komplexképző sajátságát vizsgáltuk. Köztük két olyan $\mathrm{Gd}^{3+}$-komplex is volt, amelyek néhány év múlva engedélyezett, ma is használt kontrasztanyagok: a Gadovist $(\mathrm{Gd}(\mathrm{B}-\mathrm{DO} 3 \mathrm{~A}))$ és a Primovist $\left(\mathrm{Na}_{2} \mathrm{Gd}(\mathrm{EOB}-\mathrm{DTPA})\right)$ [35-37].

Terveztük olyan makrociklusos ligandumok előállítását, melyek a makrocikluson „hordják” a negatív töltést a foszfinát csoport bevitelével. Ilyen nyíltláncú ligandumok előállítása ugyan sikerült, de a makrociklusos vegyületé nem [38, 39]. Érdekes az Ln(III)-2-hidroxi-1,3-diaminopropán-tetraacetát komplexben az alkoholos $\mathrm{OH}$-csoport viselkedése, mivel nagyon kis pH értéknél disszociál. Az La(III)-komplexben $\mathrm{pH}=5$-nél, az Lu(III)-komplexben $\mathrm{pH}=1$ esetén kezdődik a disszociációja. A Ln(III)-komplexek már nagyon híg oldatban és szilárd állapotban is dimerizálódnak [40].

Számos DTPA mono-, bis- és tris-amid származékot állítottunk elö. Az amidcsoportok számának növelése csökkenti a ligandum töltését és így a komplexek stabilitását is. A ligandum töltésének csökkenése a komplexben koordinált vízmolekula cseresebességét is csökkenti. Ugyanakkor a $\mathrm{Gd}^{3+}$-komplexek fémioncsere reakcióinak sebessége az amid csoportok számának növekedésével csökken és pl. a Gd(DTPA-tris-amid) komplex inertsége jelentősen meghaladja a Gd(DTPA) inertségét [37, 41-44].

A Gd-alapú kontrasztanyagokat sokáig veszélytelen, az injektálás után teljesen kiürülő anyagoknak tekintették. Mára kiderült, hogy nagyon kis mennyiségben a szervezetben maradnak, ami súlyos vesebetegeknél a Nefrogén Szisztémás Fibrózisos betegséget okozhatja. A nyíltláncú komplexekből visszamaradó Gd nagyobbrészt a komplexek disszociációjának eredménye. A ,szabad” $\mathrm{Gd}^{3+}$-ion reakcióba lép a testfolyadékokban lévő ionokkal, pl. $\mathrm{GdPO}_{4}$ kiválásával. A makrociklusos komplexek disszociációja annyira lassú, hogy a szervezetben a kiürülésük előtt disszociációjuk nem következhet be $[45,46]$. Biofolyadékokban a foszfát, citrát, de különösen a karbonát/bikarbonát ionok katalizálják a nyíltláncú $\mathrm{Gd}^{3+}$-komplexek disszociációját vegyes komplexek képződésével (ezt ${ }^{1} \mathrm{H}$ - és ${ }^{13} \mathrm{C}-\mathrm{NMR}$ spektroszkópiával igazoltuk). A kontrasztanyagok disszociációjának sebessége a $\operatorname{Gd}($ EOB-DTPA $)<\operatorname{Gd}($ BOPTA $)<\operatorname{Gd}($ DTPA $)<$ Gd(DTPA-BMA) sorrendben nő [45-47]. 
A nemspecifikus, extracelluláris kontrasztanyagok mellett olyan Gd-komplexek előállításával is foglalkoznak, amelyek lehetővé teszik a szervezet állapotát jellemző paraméterek, pl. a szöveti $\mathrm{pH}, \mathrm{pO}_{2}$, enzim vagy endogén fémion koncentráció in vivo meghatározását. Ilyen ú.n. „intelligens" $\mathrm{pH}$ érzékeny és $\mathrm{Zn}^{2+}$ érzékeny tervezett kontrasztanyagok fizikai-kémiai tulajdonságainak jellemzésében is közremüködtünk [48-51].

A $\mathrm{Gd}^{3+}$-alapú kontrasztanyagokkal kapcsolatban felmerült toxicitási problémák miatt csoportunkban eredményesen folytak $\mathrm{Mn}^{2+}$-alapú MRI kontrasztanyagok fejlesztésével kapcsolatos munkák, melynek egy kis részében korábbi tapasztalataim alapján közremüködtem $[52,53]$.

2000 körül együttműködés alakult ki csoportunk és S. Aime professzor (Torinói Egyetem) között. Ennek keretében Kálmán Ferenc és Baranyai Zsolt volt PhD hallgatóim 2 évet dolgoztak Torinóban. Kapcsolatunk bővült a Bracco S.p.a. gyógyszergyár irányába, ami 8 évig támogatta csoportunk munkáját. Közben Baranyai Zsolt habilitált, de 4 éve a Bracco állásajánlatát elfogadta és a gyár Triesztben lévő laboratóriumát vezeti, de továbbra is együttmüködik a csoporttal.

1990-ben Dallasból történt hazatérésem után több helyről kaptunk támogatást (OTKA, Müv. Min. COST, két svájci NSF, CEEC/NIS, Schering A. G., Bracco S.p.A.), így javultak a munka feltételei, bővült csoport és jöttek is az eredmények. A Tanszék is jól müködött és 1994-ben Sóvágó Imre kollégának átadtam a Tanszék vezetését. 1991-ben felkértek a TTK Dékáni teendői ellátására, amit 1993-ig vállaltam. A dékáni feladatokkal járó tevékenységet nem élveztem, sok volt az ülés, személyi problémák, stb. Talán a gyógyszerész képzés megindítására tett első lépések jelentettek némi elégedettséget. Ebben az időben kezdődött az egyetemi oktatási rendszer átszervezése is.

Szakmai munkámat mindig intenzíven, lelkesedéssel végeztem, közben majdnem egész életemben sportoltam, amit ugyancsak lelkesen (pótolva hiányzó fizikai adottságaimat) tettem, t.i. röplabdáztam 16-tól 30 éves koromig, az utolsó 7 évben a DEAC NB I-es csapatában. A röplabdázás befejezése után hetente kétszer kosárlabdáztam, majd 40 évesen teniszezni kezdtem (Beck Mihály hívására) és 77 éves koromig rendszeresen játszottam. Néha sajnálom a sportra fordított időt, bár a pályán mindig jól éreztem magam és szellemileg kipihenve folytattam a munkát.

70 éves koromban, 2005-ben nyugdíjba mentem (emeritus professor lettem) és munkatársaim kis „Symposium”-ot szerveztek „búcsúztatásomra”, „Multiface Coordination Chemistry: Forty-five Years of Rare Earth Chemistry with Ernő Brücher" címmel. A Symposium-ra sokan eljöttek, volt tanítványaim, többen a külföldi együttmüködő partnereink közül és kollégáim, barátaim. Az emlékezés jól esett. Ugyanakkor sem kollégáim, sem én nem gondoltam, hogy a „búcsúztatás” kicsit hiábavaló, ugyanis még vagy 10 évig rendszeresen bejártam a Tanszékre és ha kérték, segítettem (már amennyiben tudtam). Ma már sokkal ritkábban megyek, de továbbra is olvasok és próbálom követni, hogy mi történik a ritkaföldfém komplexek kémiájában, az MRI kontrasztanyagok fejlesztésében.

\begin{tabular}{|c|c|c|}
\hline $\begin{array}{c}\mathrm{R}_{1} \\
\mathrm{COOH}\end{array}$ & $\begin{array}{c}\mathrm{R}_{2} \\
\mathrm{COOH}\end{array}$ & $\begin{array}{r}\mathbf{R}_{3} \\
-\end{array}$ \\
\hline $\mathrm{CH}_{2} \mathrm{OH}$ & $\mathrm{COOH}$ & - \\
\hline $\mathrm{COOH}$ & $\mathrm{COOH}$ & СНОН \\
\hline $\mathrm{COOH}$ & $\mathrm{COOH}$ & $\mathrm{PO}_{(}(\mathrm{OH})$ \\
\hline $\mathrm{COOH}$ & $\mathrm{COOH}$ & $\left(\mathrm{CH}_{2)_{4}}\right.$ \\
\hline $\mathrm{OH}$ & $\mathrm{COOH}$ & $\begin{array}{l}\mathrm{H}_{2} \mathrm{C}_{-} \mathrm{OCH}_{2} \\
\mathrm{H}_{2} \mathrm{C}-\mathrm{OCH}_{2}\end{array}$ \\
\hline
\end{tabular}
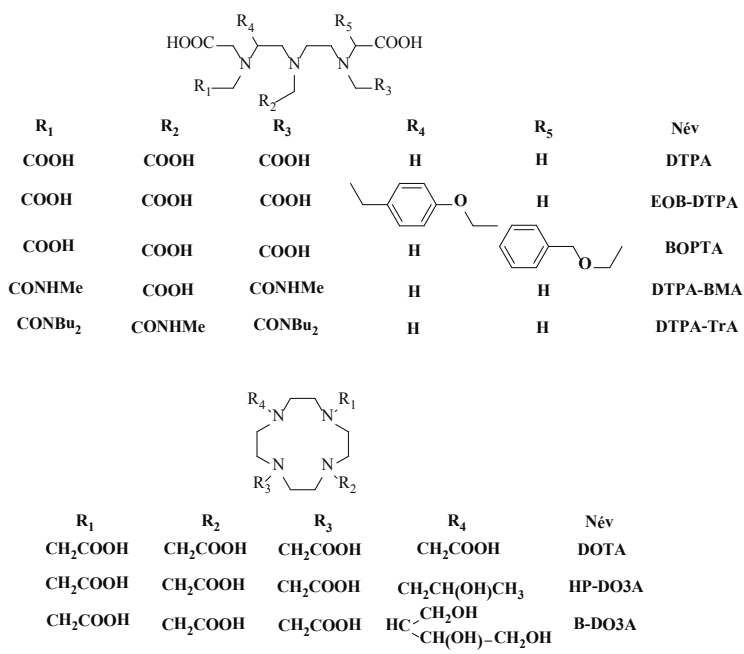

1. Ábra. A vizsgált ligandumok szerkezete

\section{Köszönetnyilvánítás}

A szerző hálásan köszöni Dr. Molnár Enikő és Takács Katalin kolleganőknek a kézirat elkészítésében nyújtott segítségét.

\section{Hivatkozások}

1. Brücher E. ATOMKI Közlemények, 1962, 4, 37-43.

2. Brücher E. Radiokhimiya, 1963, 5, 142-143.

3. Brücher E.; Szarvas P. J. Inorg. Nucl. Chem. 1966, 28, 23612369.

https://doi.org/10.1016/0022-1902(66)80127-6

4. Spedding F. H.; Powell J. E.; Wheelwright E. J. J. Am. Chem. Soc. 1954, 76, 2550-2557. https://doi.org/10.1021/ja01638a074

5. Brücher E.; Szarvas P. in Proceeding of $3^{\text {rd }}$ analytical conference, vol. 1. Budapest 1970, Akadémiai Kiadó, Szerk. Buzás I., 27-33.

6. Brücher E.; Szarvas P. Inorg. Chim. Acta, 1970, 4, 632-636. https://doi.org/10.1016/S0020-1693(00)93367-X

7. Brücher E.; Szarvas P. Acta. Chim. Acad. Sci. Hung. 1967, 52, 31-35.

8. Brücher E.; Kostromina N. A. Teoret. Ekszper. Him. 1972, 8, 210-215.

9. Brücher E.; Kukri Cs. É.; Zékány L. J. Inorg. Nucl. Chem. 1974, 36, 2620-2623. https://doi.org/10.1016/0022-1902(74)80486-0 
10. Brücher E.; Király R.; Nagypál I. J. Inorg. Nucl. Chem. 1975, 37, 1009-1012. https://doi.org/10.1016/0022-1902(75)80688-9

11. Brücher E.; Király R.; Tóth I. Inorg. Nucl. Chem. Letters, 1976, 12, 167-171. https://doi.org/10.1016/0020-1650(76)80193-6

12. Brücher E.; Tóth I. Radiochem. radioanal. Letters, 1972, 12, 53-58.

13. Burai L.; Hietapelto V.; Király R.; Tóth É.; Brücher E. Magnet. Reson. Med. 1997, 38, 146-150. https://doi.org/10.1002/mrm.1910380120

14. Brücher E.; Zékány L. J. Inorg. Nucl. Chem. 1981, 43, 351-356.

https://doi.org/10.1016/0022-1902(81)90022-1

15. Brücher E.; Laurenczy G. Inorg. Chem. 1983, 22, 338-342. https://doi.org/10.1021/ic00144a027

16. Brücher E.; Laurenczy G. J. Inorg. Nucl. Chem. 1981, 43, 2089-2096. https://doi.org/10.1016/0022-1902(81)80555-6

17. Laurenczy G.; Radics L.; Brücher E. Inorg. Chim. Acta, 1983, $75,219-223$. https://doi.org/10.1016/S0020-1693(00)91216-7

18. Brücher E.; Bányai I. J. Inorg. Nucl. Chem. 1980, 42, 749-756. https://doi.org/10.1016/0022-1902(80)80225-9

19. Brücher E.; Bányai I.; Krusper L. Acta Chim. Hung. 1984, 116, 39-50.

20. Brücher E.; Kukri Cs. É.; Király R. Inorg. Chim. Acta, 1984, 95, 135-139. https://doi.org/10.1016/S0020-1693(00)87609-4

21. Brücher E.; Glaser J.; Grenthe I.; Puigdomènech I. Inorg. Chim. Acta, 1985, 109, 111-115. https://doi.org/10.1016/S0020-1693(00)84550-8

22. Brücher E.; Glaser J.; Tóth I. Inorg. Chem. 1991, 30, 22392241. https://doi.org/10.1021/ic00009a055

23. Tóth É.; Brücher E.; Lázár I.; Tóth I. Inorg. Chem. 1994, 33, 4070-4076. https://doi.org/10.1021/ic00096a036

24. Burai L.; Fábián I.; Király R.; Szilágyi E.; Brücher E. J. Chem. Soc. Dalton Trans. 1998, 243-248. https://doi.org/10.1039/a705158a

25. Brücher E.; Sherry A. D. Inorg. Chem. 1990, 29, 1555-1559. https://doi.org/10.1021/ic00333a022

26. Cortes S.; Brücher E.; Geraldes C. F. G. C.; Sherry A. D. Inorg. Chem. 1990, 29, 5-9. https://doi.org/10.1021/ic00326a003

27. Ramasamy R; Lázár I.; Brücher E.; Sherry A. D. FEBS Letters, 1991, 280, 121-124. https://doi.org/10.1016/0014-5793(91)80218-R

28. Lázár I.; Sherry A. D.; Ramasamy R.; Brücher E.; Király R. Inorg. Chem. 1991, 30, 5016-5019. https://doi.org/10.1021/ic00026a030

29. Brücher E.; Stefan S. L.; Allen D. R.; Sherry A. D. Radiochimica Acta, 1993, 61, 207-212. https://doi.org/10.1524/ract.1993.61.34.207

30. Sherry A. D.; Ren J.; Huskens J.; Brücher E.; Tóth É. Inorg Chem. 1996, 35, 4604-4612. https://doi.org/10.1021/ic9600590

31. Burai L.; Ren J.; Kovács Z.; Brücher E.; Sherry A. D. Inorg. Chem. 1998, 37, 69-75. https://doi.org/10.1021/ic970599c

32. Brücher E.; Győri B.; Emri J.; Jakab S.; Kovács Z.; Solymosi P.; Tóth I. J. Chem. Soc. Dalton Trans. 1995, 3353-3357. https://doi.org/10.1039/DT9950003353

33. Micskei K.; Helm L.; Brücher E.; Merbach A. E. Inorg. Chem. 1993, 32, 3844-3850. https://doi.org/10.1021/ic00070a013
34. Micskei K.; Powell D. H.; Helm L.; Brücher E.; Merbach A. E. Magnet. Reson. Chem. 1993, 31, 1011-1020. https://doi.org/10.1002/mrc.1260311111

35. Tóth É.; Király R.; Platzek J.; Radüchel B.; Brücher E. Inorg. Chim. Acta, 1996, 249, 191-199. https://doi.org/10.1016/0020-1693(96)05094-3

36. Szilágyi E.; Tóth É.; Kovács Z.; Radüchel B.; Brücher E. Inorg. Chim. Acta, 2000, 298, 226-234. https://doi.org/10.1016/S0020-1693(99)00467-3

37. Sarka L.; Bányai I.; Brücher E.; Király R.; Platzek J.; Radüchel B. J. Chem. Soc. Dalton Trans. 2000, 3699-3703. https://doi.org/10.1039/b0052981

38. Varga T.; Király R.; Brücher E.; Hietapelto V. ACH-Models in Chemistry, 1999, 136, 431-439.

39. Tircso G.; Bényei A.; Király R.; Lázár I.; Pál R.; Brücher E. Eur. J. Inorg. Chem. 2007, 701-713. https://doi.org/10.1002/ejic.200600891

40. Tircso G.; Bényei A.; Brücher E.; Kiss A.; Király R. Inorg. Chem. 2006, 45, 4951-4962. https://doi.org/10.1021/ic0517321

41. Brücher E.; Jászberényi Z.; Király R.; Sarka L. J. Inorg. Biochem. 2001, 86, 26-31.

42. Sarka L.; Burai L.; Király R.; Zékány L.; Brücher E. J. Inorg. Biochem. 2002, 91, 320-326. https://doi.org/10.1016/S0162-0134(02)00418-X

43. Jászberényi Z.; Brücher E.; Jekő J.; Hideg K.; Kálai T.; Király R. Eur. J. Inorg. Chem. 2003, 3601-3608. https://doi.org/10.1002/ejic.200300059

44. Jászberényi Z.; Tóth É.; Kálai T.; Király R.; Brücher E.; Merbach A. E. Dalton Trans. 2005, 694-701. https://doi.org/10.1039/B417272H

45. Sarka L.; Burai L.; Brücher E. Chem. Eur. J. 2000, 6, 719-724. https://doi.org/10.1002/(SICI)1521-3765(20000218)6:4<719:: AID-CHEM719>3.0.CO;2-2

46. Baranyai Zs.; Pálinkás Z.; Uggeri F.; Maiocchi A.; Aime S.; Brücher E. Chem. Eur. J. 2012, 18, 16426-16435. https://doi.org/10.1002/chem.201202930

47. Baranyai Zs.; Brücher E.; Uggeri F.; Maiocchi A.; Tóth I.; Andrási M.; Gáspár A.; Zékány L. Chem. Eur. J. 2015, 21, 4789-4799.

https://doi.org/10.1002/chem.201405967

48. Kálmán F.; Woods M.; Caravan P.; Spiller M.; Tircso G.; Brücher E.; Sherry A. D. Inorg. Chem. 2007, 46, 5260-5270. https://doi.org/10.1021/ic0702926

49. Kálmán F.; Baranyai Zs.; Tóth I.; Bányai I.; Király R.; Brücher E.; Aime S.; Sherry A. D.; Kovács Z. Inorg. Chem. 2008, 47, 3851-3862. https://doi.org/10.1021/ic7024704

50. Takács A.; Napolitano R.; Purgel M.; Bényei A.; Zékány L.; Brücher E.; Tóth I.; Aime S. Inorg. Chem. 2014, 53, 28582872. https://doi.org/10.1021/ic4025958

51. Tircso G.; Tircsóné Benyo E.; Garda Z.; Singh J.; Trokowski R.; Brücher E.; Sherry A. D.; Tóth É.; Kovács Z. J. Inorg. Biochem. 2020, 206, 111042. https://doi.org/10.1016/j.jinorgbio.2020.111042

52. Molnár E.; Váradi B.; Garda Z.; Botár R.; Kálmán F.; Tóth É.; Platas-Iglesias. C.; Tóth I.; Brücher E.; Tircso G. Inorg. Chim. Acta, 2018, 472, 254-263. https://doi.org/10.1016/j.ica.2017.07.071

53. Garda Z.; Molnár E.; Kálmán F.; Botár R.; Nagy V.; Baranyai Zs.; Brücher E.; Kovács Z.; Tóth I.; Tircso G. Frontiers in Chemistry 2018, 6, 1-14.

https://doi.org/10.3389/fchem.2018.00232 


\section{Abstract}

Ernő Brücher graduated in Chemistry at the Kossuth University, Debrecen in 1958. From 1958 to 1963 he worked for the Institue of Nuclear Research of the Hungarian Academy of Sciences. He did radiochemical separations, preparations of radioactive isotopes of rare earth mainly by ion-exchange chromatography and investigated the mechanisms of separations. Based on those studies he prepared his Thesis for PhD in 1965. The fall of 1963 he joined in the staff of the Department of Inorganic and Analytical Chemistry of the Kossuth University. He supervised the laboratory work of students in general and inorganic chemistry. His research interest remained the separation and coordination chemistry of rare earth ions $(\operatorname{Ln} 3+)$. The kinetic study of the exchange reactions of the central metal ions of the $\operatorname{Ln}($ EDTA) complexes helped to find a relationship between the efficacy of ion-exchange separations and the dissociation rates of the $\operatorname{Ln}($ EDTA) complexes. Besides, he found an inverse proportionality between the stability constants of the aminopolycarboxylate (APC) complexes and their dissociation rates.

At the start of the 1970s a small research group was formed around him and they studied the equilibrium, kinetic and structural properties of the different $\mathrm{Ln}(\mathrm{III})$-APC complexes.

The interest in the coordination chemistry of Ln(III) ions has increased from the mid-1980s due to the introduction of magnetic resonance imaging examinations with the use of Gd-based contrast agents. He proposed the importance of the kinetic stability of the Gd-complexes for the safety of those agents. They studied the complex formation, stability constants, relaxivities and dissociation rates of several DTPA-amid derivative complexes of Gd(III) and derived a general rate equation that involve all the possible reaction pathways where the decomplexation could oc- cur. They found that the decomplexation of the DTPA-derivative contrast agents in biofluids occurs by dissociation assisted by citrate, phosphate and predominantly by bicarbonate/carbonate ions and the rates of dissociation of complexes increases in the order: $\operatorname{Gd}($ EOB-DTPA $)<$ Gd(BOPTA) $<$ Gd(DTPA) $<$ Gd(DTPABMA). The macrocyclic DOTA derivative Gd(III)-complexes are formed slowly and the mechanism they proposed for the formation reactions was in agreement with the experimental data. The decomplexation of the Gd-DOTA derivative complexes occurs by their proton assisted dissociation that is very slow at $\mathrm{pH}=7.4$. The rate of exchange of the water molecule coordinated in the inner sphere of both the DTPA and DOTA derivative contrast agents were found to be relatively slow that may effect the relaxivities.

The number of his publications in referred journals and book chapters is around 170 .

Ernő Brücher had a position of assistant professor (1968), associated professor (1970) and full professor (1983). He was elected the chairman of Institute of Chemistry between 1975-78 and 1986-88. He was the Head of the Department from 1980 to 1994 and the Dean of the Faculty of Natural Sciences between 1991 and 1993.

He spent longer time and worked in the Institute of Inorganic Chemistry of the Ukrainian Academy in Kiev, The Royal Institute of Technology in Stockholm, The University of Lausanne, The University of Texas at Dallas.

Several members of his group who obtained PhD degree with him in Debrecen became university professors there or abroad or did carrier in the industry. 